Review

\title{
Homeopathy in Epidemics: From Cholera to 1918 Spanish Flu (Part 2)
}

\author{
Francesco E. Negro ${ }^{1,}{ }^{*}$, Francesco V. Marino ${ }^{2}$
}

1. Fondazione Negro-Museo di Storia dell’Omeopatia, Roma, Italy; E-Mail: negro.fe@iol.it

2. FIAMO-Federazione Italiana delle Associazioni e dei Medici Omeopati, Roma, Italy; E-Mail: dr.fmarino@gmail.com

* Correspondence: Francesco E. Negro; E-Mail: negro.fe@iol.it

\section{Academic Editor: Bruno Galeazzi}

Special Issue: $\underline{\text { Homeopathy }}$

OBM Integrative and Complementary Medicine

2021, volume 6, issue 4

doi:10.21926/obm.icm.2104045
Received: April 26, 2021

Accepted: September 28, 2021

Published: November 07, 2021

\begin{abstract}
The 19th century saw an explosion of serious epidemic diseases, such as smallpox and scarlet fever, which led to the development of an alternative system of medicine called homeopathy. Under this system, S. Hahnemann developed a rigorous methodology based on repeated observations on the field, leading to successful results. The aim of this work is to depict the birth and evolution of his thought. The correct understanding and application of this methodology became the reference model for subsequent generations of homeopaths, who successfully treated some epidemics, such as cholera and Spanish flu. Although these results were well-documented, they were not recognized by the academic community; however, they gave a great impulse to the worldwide spread of homeopathy.
\end{abstract}

\section{Keywords}

Methodology; vaccination; scarlet fever; cholera; Spanish flu; pandemic

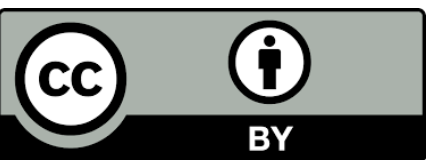

(C) 2021 by the author. This is an open access article distributed under the conditions of the Creative Commons by Attribution License, which permits unrestricted use, distribution, and reproduction in any medium or format, provided the original work is correctly cited. 


\section{Homeopathy and the Cholera Epidemic of the Nineteenth Century: The Italian Case}

During the nineteenth century, six cholera epidemics plagued Italy and Europe (1834-37, 1848$49,1854-55,1865-67$, and $1884 ; 1893)$. It turned out to be a deadly disease as its origin and treatment were unknown. However, it is interesting to note that homeopaths reported better treatment results as compared to their conventional counterparts.

In Italy alone, from 1836 to 1867 , homeopaths treated 6,238 cholera patients with a mortality rate of $7.39 \%$ [1]. Out of these homeopaths, the experience of Dr. Rocco Rubini was particularly significant. By following Hahnemann's instructions [2], Rubini modified the formulation of Camphora, which, in the cold state of cholera, proved to be the most suitable remedy. Hahnemann in his text suggested 1 ounce of Camphora in 12 of alcohol. Rubini instead used a saturated solution of alcohol and camphor 1: 1 and administered 3-4 drops every 5 minutes: the famous CAMPHORA RUBINI [3].

Thanks to this solution, Rubini was able to treat 200 cholera patients at the Reale Albergo dei Poveri (Naples) within three months (27 July-11 September 1854), without registering any deaths [3].

In addition, during this period, a Swiss regiment was present in Naples, and 183 cases of cholera were reported among them. Out of them, 166 patients were hospitalized at the above-mentioned institute, and all were treated and healed homeopathically. Whereas, out of the 17 soldiers hospitalized at the Hospital of the Trinity and subjected to conventional therapies, only two were saved.

Due to these continuous epidemic waves and the success of homeopathic treatment, in 1861-62, the first homeopathic hospital (S. Maria della Cesarea) was established in Naples. Here, Rubini treated 378 patients suffering from typhus homeopathically with a mortality of $2 \%$ [3].

These successes, confirmed by official statistics, provoked a series of hostile reactions from the academic profession. As a result, in 1863, Rubini was fired and replaced by a coroner (A. Ciccone), who was one of the strongest opponents of homeopathy. Since then, all the homeopathic initiatives have been systematically hindered. During the epidemic situations of 1856 and 1866, the Neapolitan institutions refused the treatments offered free of charge by other homeopaths (Mengozzi, Cappelli, and Simonetti). Such hostility caused a drastic reduction in the number of homeopaths - from 500 in 1834 to 184 in 1863 . The opposition reached its peak during the epidemic of 1884, during which time; the institutions rejected Rubini's free work and even subjected him to strict fiscal control. Rubini was forced to sell his assets and erased from the professional register [4].

\section{Homeopathy in the 1918 Pandemic}

Similar to the cholera epidemic, homeopathic physicians achieved significant success in treating the flu pandemic as compared to their academic colleagues; and, in this case, also, their merits were ignored or underestimated. The interesting fact that emerged from their experiences was the extraordinary agreement both in the use of medicines and in the statistics reported and published in the journals of the time-a low mortality rate of $2.1-5 \%$ in the case of homeopathy against $40-$ $60 \%$ in the case of conventional therapies. Unfortunately, the censorship of the military institutions, because of the war, did not allow homeopathic doctors of the European countries to disseminate and publish data about the Spanish flu. This is the main reason why we have no significant reports 
from Italy and the other belligerent countries. In those years, the main Italian homeopathic journals ceased publication, and the number of homeopathic doctors gradually decreased in the 1930s. With the exception of A. Nebel [5] (who, among other things, in 1938 developed the nosode "Influenzinum " [6]), only Spanish (in Europe) and American homeopaths have left us evidence of the work done.

\subsection{The Spanish Experience}

The work published by Dr. A. Olivè (co-director) together with A. Vinyales in the November 1918 issue of the Revista de Homeopatia Practica has been considered the reference point here [7].

In Spain, the flu cases began in March, first in a mild form, then in an increasingly epidemic form, with a severe expression. Apart from generic prophylaxis, such as how to avoid gatherings (a city ordinance required public transport to operate with the doors open to facilitate ventilation) and normal suggestions about hygiene, respiratory and oral prophylaxis was also recommended (sodium perborate and diluted hydrogen peroxide), which focused on avoiding sudden changes in temperature that could affect the mucous membranes of the respiratory tract. These measures adopted by homeopaths were based on the principles that Hahnemann had indicated in "The friend of health" [8]. In the analysis of these cases, the study of individual variables was fundamental.

The most frequently prescribed remedies were Aconitum, Veratrum Viride, Belladonna, Eupatorium, Bryonia, Ipeca, Antimonium Tartaricum, and Phosphorus. In the period of convalescence, these medicines were given in combination with China, Nux Vomica, and Arsenicum album. In cases of hemoptysis and hematemesis, the prescribed remedies were Millefolium, Trillium pend, and Ham.

In the Review, a work by Dr. J. Girò Savall $[9,10]$ illustrates the effectiveness of homeopathy in treating various symptoms of the epidemic and its complications (pneumonia, bleeding, and involvement of the digestive system). The general symptomatology was characterized by insomnia, inappetence, generalized asthenia, sudden onset and long persistence of symptoms, frequent relapses, and unpredictability of manifestations. Fatigue, in benign cases, was accompanied by the desire for immobility, a feeling of fatigue with no apparent cause, and refusal to move. In severe cases, precordialgia, tachycardia, coldness, and rapid death were accompanied by the previous symptoms.

The drugs mainly used in the therapy, in low dilution, were the following: Bryonia, Aconitum, Eupatorium, Nux Vomica, Phosphorus, Rhus Tox, Veratrum Viride, Baptisia, Gelsemium, Chininum Sulfuricum, Ipecacuanha, Tartarus emeticus, Arsenicum, Carbo Vegetabilis, Ranunculus, Cantharis, Iodum, Opium, Ignatia, Apium virus, China, Colocynthis, Mercurius Corrosivus, Veratrum album, Colchicum, Chelidonium, Ferrum Phosphoricum, Allium cepa, Phosphoricum acidum, Hydrastis, Secale Cornutum, Millefolium, Lachesis, and Crotalus. The drugs used during convalescence include Avena sativa, Arsenicum, China, and Gelsemium. The prophylactic medicines used were Rhus Toxicodendron, Bryonia, and Eupatorium, with the addition of dietary principles.

Girò Savall also reports that over 150 cases were treated at the Nino Dias Homeopathic Hospital. Among them, 46 bronchopneumonia were cured, and only one death was reported. 


\subsection{The American Experience}

The experience of American homeopaths was much richer and more significant and was widely documented in the "Journal of the American Institute of Homeopathy" [11]. This is confirmed by the article written by Dr. A. Dewey [12], who collected the case histories of 50 American homeopaths; their clinical experiences showed an amazing concordance in the percentages of cured cases (90-97\%) and in the remedies used (similar to the Spanish homeopaths but were administered on more cases) .

Another interesting fact, confirmed by all American homeopaths, was the observation of the suspected adverse effects of aspirin - the drug recommended by the health authorities. The megadoses, recommended by the US Minister of War (from 8 to $31 \mathrm{gr} /$ day), resulted in the aggravation of the sick, evolving toward hemorrhagic pneumonia in already seriously compromised subjects [13]. These effects may be due to the then-unknown powerful anticoagulant effect. According to Dr. A. Williams (Rhode Island), aspirin caused death in $60 \%$ of patients who developed pneumonia [12].

In Philadelphia, Dr. Dean W. Pearson collected 26,795 cases treated by various homeopaths, which had much lower mortality of $1.05 \%$ compared with $30 \%$ of allopaths. Also, in Philadelphia, Dr. E. F. Sappington reported that 1,500 patients were treated at the District of Columbia Society of Homeopathic Medicine with only 15 deaths, while 100\% recovery was achieved at the National Homeopathic Hospital.

In New York, the International Homeopathic Association also reported relevant statistics17,000 patients (with many cases of pneumonia) with a mortality of $0.25 \%$. Another famous homeopath, Herbert A. Roberts, sent a questionnaire to 30 homeopaths in Connecticut; the answers revealed that 6,602 patients were treated, and only 55 deaths (1\%) were reported. He himself, embarked at that time on a merchant fleet, treated 81 patients homeopathically - all were healed and regularly disembarked. Dr. Frank Wieland of Chicago successfully treated, using Gelsemium, 8,000 factory workers, recording only one death.

Dr. Mary Senseman (Illinois) treated 49 bedridden subjects (immobile, congested, complaining, unwilling, or asking for anything) with Bryonia $10 \mathrm{M}$ and 23 others (with sticky nose and mouth mucus) with Senega 1M-10M.

Dr. T. McCann (Ohio) treated over 1,000 cases without any death, using four remedies: Gelsemium, Bryonia, Eupatorium, and Arsenicum.

\section{Conclusions}

Despite the limitations coming from clinical reports collected more than one century ago, the encouraging results reported support the affirmation that the adequate application of the homeopathic methodology developed by Hahnemann led to successful management of the disastrous health emergencies of the past (cholera, flu pandemic, yellow fever, etc.) and of the present, such as: Cholera in Peru [13], infantile Diarrhea in Nicaragua [14], Leptospirosis in Cuba [15], Dengue in Brazil [16], Chikungunya in India [17], Swine flu in India [18]. Although there is still a certain hostility toward homeopathic medicine, these reported results give a historical overview of the potential displayed by homeopathy in the treatment of epidemics in the past. We have reported some historical facts about the conflict between conventional medicine and homeopathy, wishing to stimulate a more collaborative approach and to overcome suspicion and hostility, in the 
interest of the sick. Since the present COVID-19 pandemic is posing a challenge both for individuals and health systems, we are convinced that a wise and prudential integration of homeopathic preventative and therapeutic resources, apart from the conventional preventative and therapeutic approaches, could be explored. This must be performed by following the general recommendations included in the WHO Traditional Medicine Strategy 2014-2023 [19], which encourages the member states to adopt active health policies to integrate the traditional and complementary medical approaches into the national health systems in order to offer "the right care, from the right practitioner, at the right time".

\section{Author Contributions}

Dr. F. Negro contributed to Conceptualization and historical research; Dr. Marino contributed to text writing and proofreading.

\section{Competing Interests}

The authors have declared that no competing interests exist.

\section{Reference}

1 Palombi Martorano V. Napoli e la nascita dell'Omeopatia in Italia (1822). Le Stagioni d'Italia. 1990.

2 Segantini S, Marchitiello MA. La Medicina dell'esperienza e altri scritti minori di Hahnemann. Editorium 1993.

3 Galantini S. Scritti di Rocco Rubini. Teramo: Ricerche e Redazioni; 2004.

4 Nebel A. La gripe española. Editorial Mínima; 2006. p. 36-37.

5 Julian OA. Materia Medica of Nosodes with Repertory. India: B. Jain Publishers Ltd; 1980.

6 Olivè A. Epidemia gripal. Revista de Homeopathia Practica V. 1918.

7 Schmidt JM. Bibliographie der Schriften Samuel Hahnemanns. Rauenberg, German: Open Access LMU; 1989. doi: 10.5282/ubm/epub.17933.

8 Giró Savall J. La epidemia reinante, la superioridad del tratamiento homeopático. Revista de Homeopatía Práctica. 1918.

9 Journal of the American Institute of Homeopathy. voll. XI. 1919.

10 Journal of the American Institute of Homeopathy. voll. XII. 1920.

11 Dewey WA. Homeopathy in influenza- A chorus of fifty in harmony. J Am Inst Homeopathy. 1921: 1038-1043.

12 Karen M. Salicylates and pandemic influenza mortality, 1918-1919 pharmacology, pathology, and historic evidence. Clin Infect Dis. 2009; 49: 1405-1410.

13 Gaucher C, Jeulin D, Peycru E, Amengual C. A double blind randomized placebo controlled study of cholera treatment with highly diluted and succussed solutions. Homeopathy. 1993; 82: 126.

14 Jacobs J, Jonas WB, Jimenez-Perez M, Crothers D. Homeopathy for childhood diarrhea: Combined results and metaanalysis from three randomized, controlled clinical trials. Pediatr Infect Dis J. 2003, 22: 229-234

15 Bracho G, Varela E, Fernández R, Ordaz B, Marzoa N, Menendez J, et al. Large-scale application of highly-diluted bacteria for Leptospirosis epidemic control. Homeopathy. 2010; 99: 156-166. 
16 de Souza Nunes LA. Contribution of homeopathy to the control of an outbreak of dengue in Macaè, Rio de Janeiro. Int J High Dilution Res. 2008; 7: 25.

17 Wadhwani G. Homeopathic drug therapy Homeopathy in Chikungunya Fever and PostChikungunya Chronic Arthritis: An observational study. Homeopathy. 2013; 102: 193-198.

18 Mathie RT, Baitson ES, Frye J, Nayak C, Manchanda RK, Fisher P. Homeopathic treatment of patients with influenza-like illness during the 2009 A/H1N1 influenza pandemic in India. Homeopathy. 2013; 102: 187-192.

19 WHO traditional medicine strategy 2014-2023. Geneva, Switzerland: World Health Organization; 2013. Available from: https://www.who.int/publications/i/item/9789241506096.

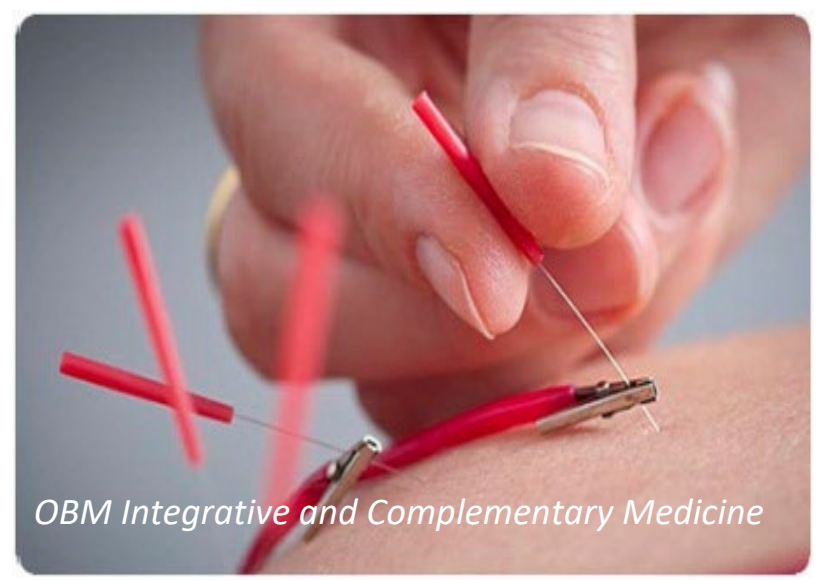

Enjoy OBM Integrative and Complementary Medicine by:

1. Submitting a manuscript

2. Joining in volunteer reviewer bank

3. Joining Editorial Board

4. Guest editing a special issue

For more details, please visit:

http://www.lidsen.com/journals/icm 